\title{
New Seismic Methods to Support Sea-Ice Platform Drilling
}

\author{
by Marvin A. Speece, Richard H. Levy, David M. Harwood,
} Stephen F. Pekar, and Ross D. Powell

\section{Introduction}

The ANtarctic geological DRILLing Program (ANDRILL) is currently a consortium of five nations (Germany, Italy, New Zealand, the United Kingdom, and the United States of America). By drilling, coring and analyzing stratigraphic archives along the Antarctic continental margin, ANDRILL pursues its primary goal of better understanding the role the Antarctic cryosphere plays in the global climate system (Harwood et al., 2006). The ANDRILL drilling system was developed to operate on both ice shelf and sea-ice platforms (Harwood et al., 2006; Falconer et al., 2007; Naish et al., 2007; Florindo et al., 2008). While thick multiyear sea ice provides stable and safe drilling platforms, identifying drilling targets in regions where these sea-ice conditions occur can be problematic due to a paucity of marine seismic reflection data because near-constant sea ice limits ship access (Fig. 1). In response to this problem ANDRILL developed new over-sea-ice seismic methods to extend seismic reflection data coverage to regions of multiyear sea ice.

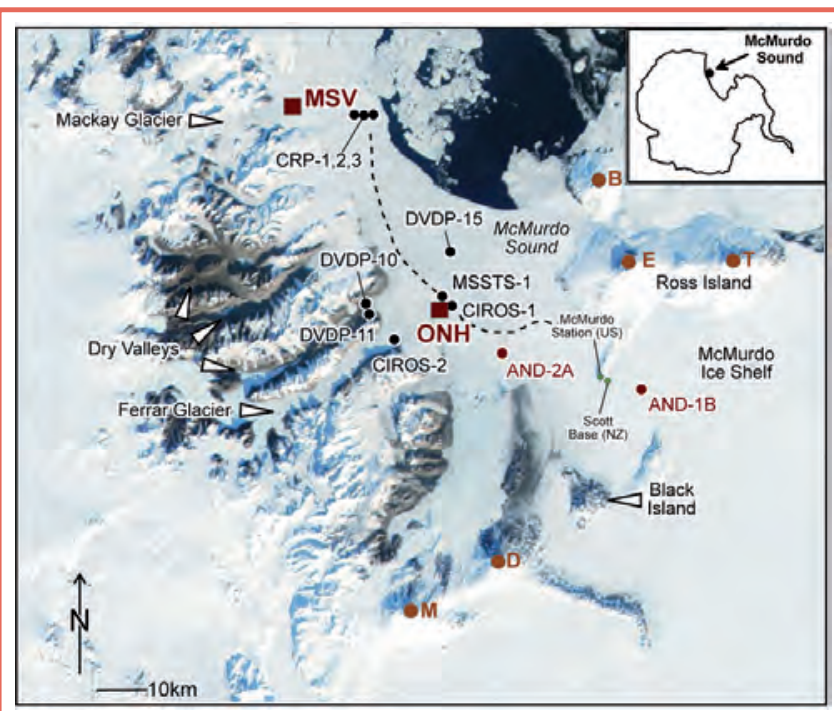

Figure 1. Location of key geographical features in southern McMurdo Sound, plus inset of Antarctica. The volcanic centers of Erebus (E), Terror ( $\mathrm{T})$, Bird (B), Discovery (D), and Morning (M) are annotated. The location of the two completed ANDRILL drill holes, AND-1B (McMurdo Ice Shelf), and AND-2A (Southern McMurdo Sound Project) are shown. The dashed line indicates the approximate margin of multiyear sea ice. Regions targeted for possible future drilling from sea-ice platforms include Offshore New Harbor $(\mathrm{ONH})$ and Mackay Sea Valley (MSV). Also shown are the locations of previous stratigraphic drill holes (DVDP, CIROS, MSSTS, and CRP) (Modified after ANDRILL International Science Proposal, 2003; NASA MODIS image I.D.: Antarctica.A2001353.1445.250m).

\section{Over-Sea-Ice Seismic Surveys}

Previous over-sea-ice seismic experiments had limited success due to (1) poor source coupling caused by thin sea ice, (2) source-induced ice flexural modes that cause coherent noise, which is difficult to remove from data, and (3) source bubble-pulse effects caused by explosive seismic sources placed in the water column (Cobb, 1973; Cook, 1973; Mertz, 1981; McGinnis et al., 1985; Davy and Alder, 1989; Rendleman and Levin, 1990; Barrett et al., 2000; Bannister and Naish, 2002; Horgan and Bannister, 2004). During the austral spring-summer of 2005, approximately $28 \mathrm{~km}$ of over-sea-ice seismic reflection data were recorded in McMurdo Sound, Antarctica (Fig. 2) for ANDRILL's Southern McMurdo Sound (SMS) Project (Harwood et al., 2004). ANDRILL developed seismic survey techniques for the SMS Project that improved the quality of over-sea-ice seismic data (Betterly et al., 2007). A Generator-Injector (GI) air gun was used as the seismic source (Fig. 3A). Single air-gun-source marine seismic surveys typically use a GI technique, in which a secondary air pulse is injected into the primary air pulse on a short time delay. The injection of the secondary air pulse dampens the generation of the bubble pulse. The GI air gun was lowered into the water column via holes drilled through the sea ice. The GI air gun minimized the source bubble effects that plagued previous over-sea-ice experiments in the Antarctic. Moreover, a 60-channel seismic snow streamer consisting of vertically oriented gimbaled geophones with 25-m takeout spacing was employed to aid rapid data collection (Fig. 4).

A ski-mounted insulated hut (the Thunder-Sled) housed the recording equipment and the GI air gun (Fig. 4). The interior of the hut was divided into two rooms. The forward room was devoted to the GI air gun. Data recording instruments and the GI air-gun shot control were located in the rear room of the hut. Batteries, recharged by solar panels placed on the outer walls of the hut, supplied power for the recording and GI air-gun instrumentation. A propane heater fed by external tanks heated the recording room.

A single 210-in ${ }^{3}$ GI air gun was suspended from a motorized winch. Compressed air for the air gun was stored in cylinders that were fed by a gasoline powered Bauer drive air compressor. A kerosene heater in the air-gun room and periodic injection of antifreeze kept the GI air-gun system from freezing. 

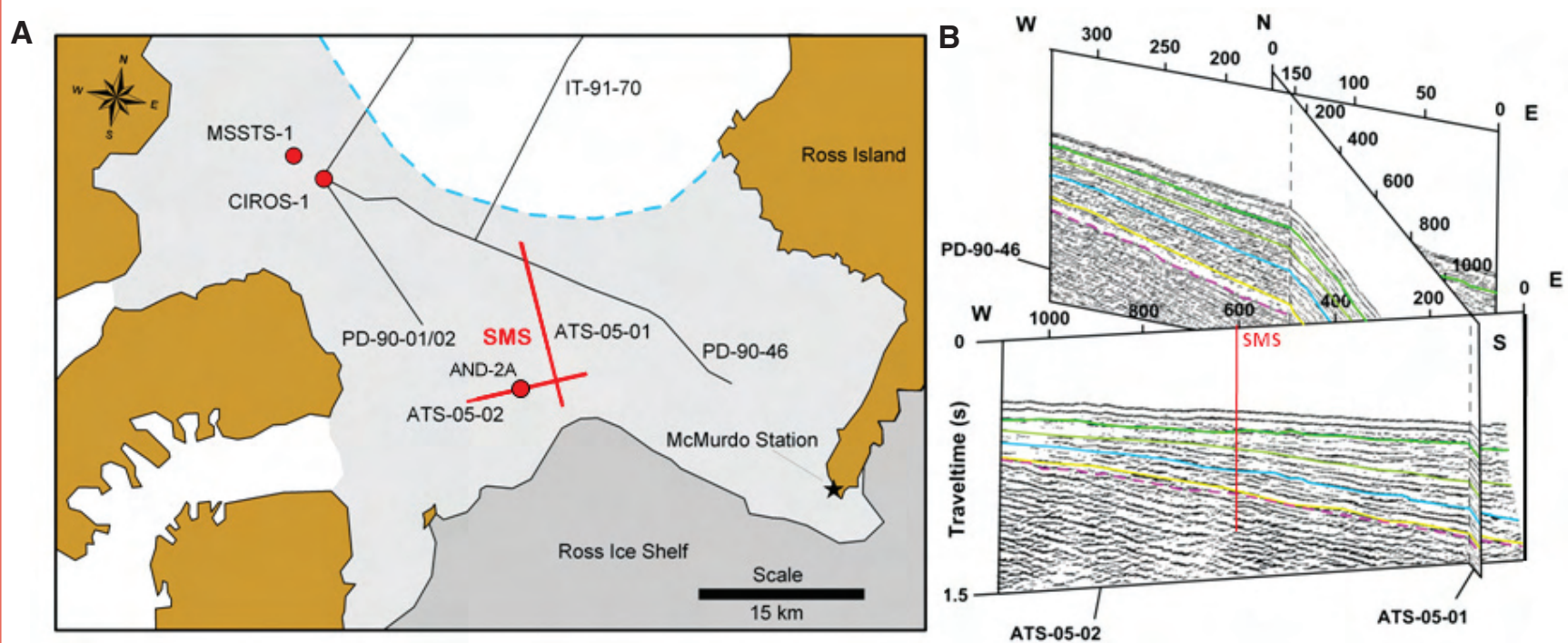

Figure 2. [A] Map of the 2005 SMS seismic survey location. The light black lines indicate existing marine seismic data (PD-90-46, PD-90-01/02, and IT-91-70), and the red lines show the location of the 2005 Southern McMurdo Sound (SMS) seismic survey (ATS-05-01 and ATS-05-02). Existing stratigraphic drill holes are labeled MSSTS-1, CIROS-1, and AND-2A in red (after Betterly et al., 2007). Dashed blue line shows the approximate extent of the 2005 ice breakout. [B] A fence diagram of PD-90-46 (single-channel marine profile), ATS-05-01, and ATS-05-02 (multichannel SMS 2005 seismic profiles) viewed from south to north. Horizontal values on ATS-05-01 and ATS-05-02 are Common MidPoint (CMP) locations. The spacing between CMP locations is $12.5 \mathrm{~m}$. Horizontal locations on PD-90-46 are shot locations with spacing of $45 \mathrm{~m}$. Each profile shows $1.5 \mathrm{~s}$ and 200 ms automatic gain control applied to these data. Colored lines overlie seismic reflectors that represent disconformities that record the advance and retreat of glaciers after the Harwood et al. (2004) interpretation.

The snow streamer consists of five cable sections with twelve takeouts per cable section. A single geophone was attached at each takeout every $25 \mathrm{~m}$ along the cable (Fig. 3B). The geophones are constructed using $30-\mathrm{Hz}$ velocity sensors that are $360^{\circ}$ roll gimbaled and have a $180^{\circ}$ pitch tolerance. Each gimbaled geophone weighs approximately $1 \mathrm{~kg}$. The cable sections have a central Kevlar stress member attached to a stainless steel cable connection. The cables are designed to remain flexible in extreme cold, and all connections are waterproof and designed to withstand a load of $13,000 \mathrm{~N}$. Special sleds were built for each cable connection to reduce the amount of drag friction from the ice and snow surface and to protect the cable heads. The streamer was pulled behind the source/recording hut, and a load cell was placed between the hut and the streamer to monitor load on the streamer (Fig. 3C).

The signal to noise ratio was increased during windy conditions by repeating air-gun shots (stacking) at each source location, then summing the shots. Seismic acquisition could be carried out in higher wind conditions if the wind blew inline, because the gimbaled geophones have a smaller profile in this direction, so wind-generated noise is minimal. Snow drifting was only a problem after major storms requiring the snow streamer to be dug out. Generally, the snow streamer could be removed from small snow drifts by

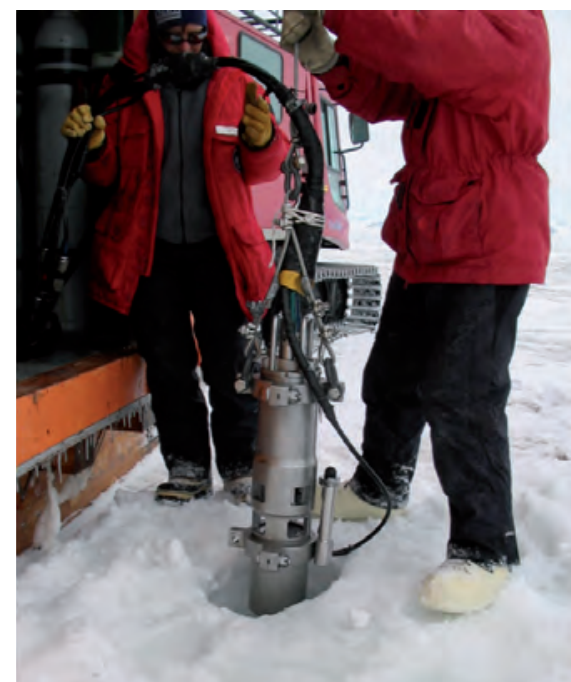

A

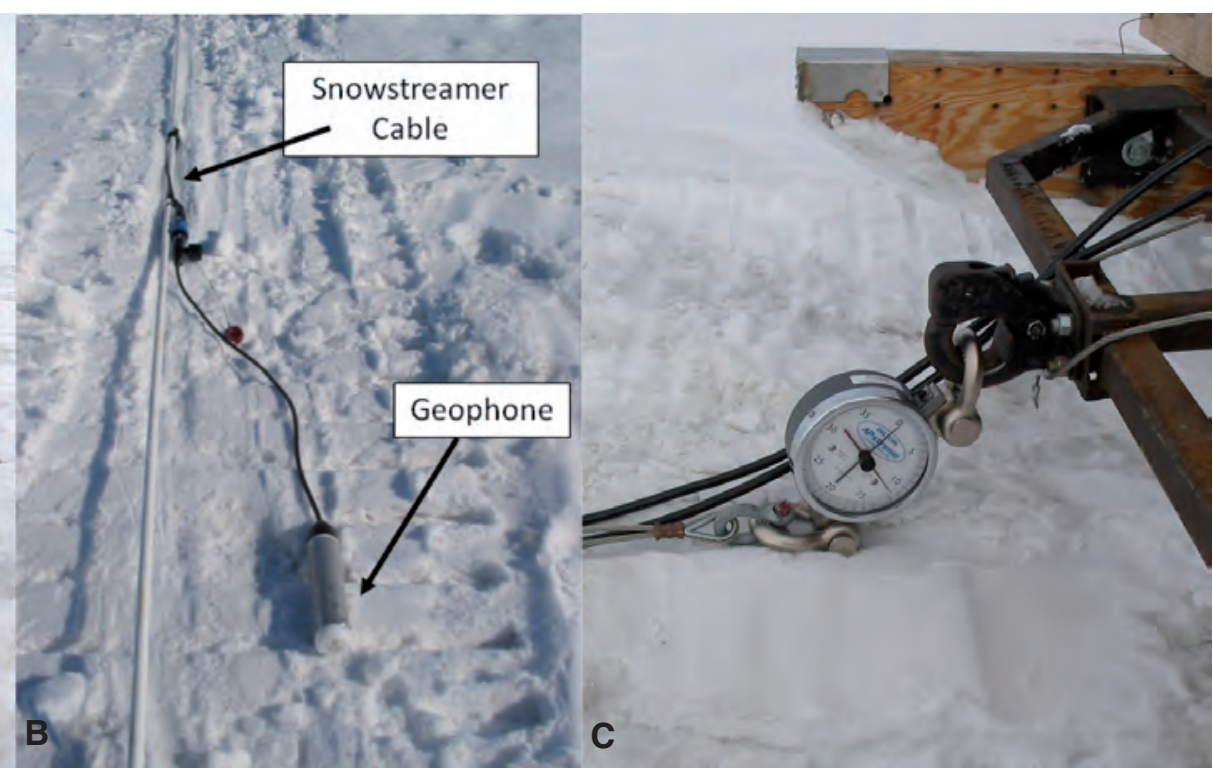

C

Figure 3. [A] Generator-Injector (GI) air gun being deployed through an auger hole in 6-m-thick sea ice; [B] Gimbaled geophone and the snow streamer cable; [C] Load cell attached to the back of the Thunder Sled and connected to a tow cable for the snow streamer (photos by R. Levy). 


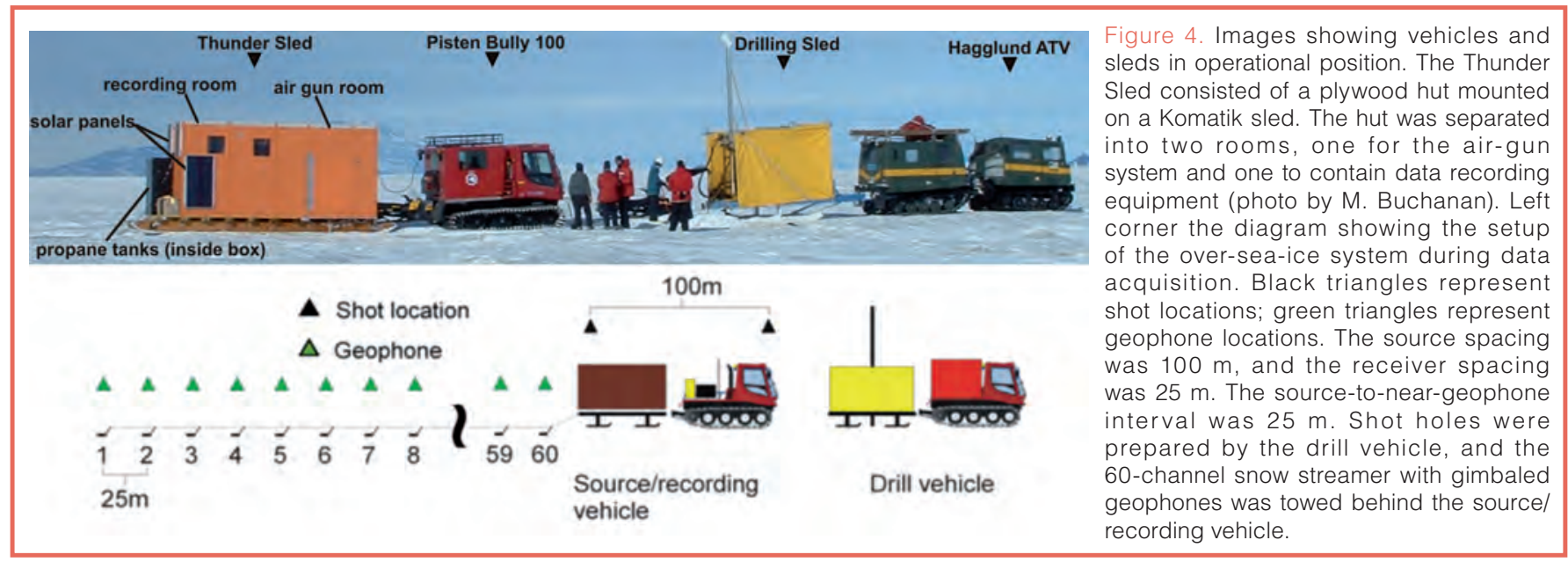

pulling it forward with a negligible force observed on the load cell.

The GI air gun provided good source coupling and minimized the source bubble effects and flexural mode problems seen in previous over-sea-ice experiments in polar regions. By extending the interpretations from nearby marine seismic surveys south to a region of thick multiyear sea ice, ANDRILL scientists were able to plan a safe location of the SMS Project drill site.

\section{Additional Successful Surveys}

During the austral summer 2007, a Vertical Seismic Profile (VSP) survey was conducted at the newly drilled SMS Project borehole. The SMS Project drill core recovered a thick succession of lower Miocene, middle Miocene, and Pliocene to Recent sedimentary rock (Florindo et al., 2008). The VSP survey used a GI air-gun source and demonstrated that high-quality borehole seismic data can be collected in a sea-ice environment. These data were collected using a three-component clamped geophone and a single near-offset source location. This is the first successful VSP survey conducted from a sea-ice platform using a GI air gun.

In addition, during the austral spring-summer 2007, ANDRILL collected approximately $20.5 \mathrm{~km}$ of high-quality seismic reflection data in Granite Harbor on the coast of southern Victoria Land. The Mackay Sea Valley (MSV; Fig. 1) is a deep trough likely formed beneath Granite Harbor by previous expansion of the Mackay Glacier. This seismic survey's intent was to image recent sediment layers that accumulated in the MSV after it had been eroded and last occupied by the ice sheet. The MSV seismic survey incorporated and refined techniques of over-sea-ice seismic data collection that had been used previously during the ANDRILL SMS seismic site survey. The MSV seismic survey was successful in locating a thin succession of low-amplitude reflections atop the higher-amplitude granite basement reflections in the deepest parts of the valley (Fig 5). The low-amplitude reflections are likely caused by layers of pelagic sediment. Future coring of these recent sediments could provide a high-resolution Quaternary climate record.

\section{Future Plans}

During the austral spring-summer 2008, an over-sea-ice multi-channel seismic reflection survey will be conducted in Offshore New Harbor (ONH; Fig. 1) to investigate the stratigraphic and tectonic history of westernmost Southern McMurdo Sound during the Greenhouse World (Eocene) into the start of the Icehouse World (Oligocene). This planned seismic survey will use over-sea-ice seismic methods employed successfully by ANDRILL's 2005 SMS and 2007 MSV surveys. A new seismic recording sled with a larger air compressor, larger air tanks, and improved air-gun winch system is being built to improve the speed and efficiency of data collection.

\section{Acknowledgements}

Prior ANDRILL drilling and site survey activities were supported by a multinational collaboration comprising four national Antarctic programs, the U.S. National Science

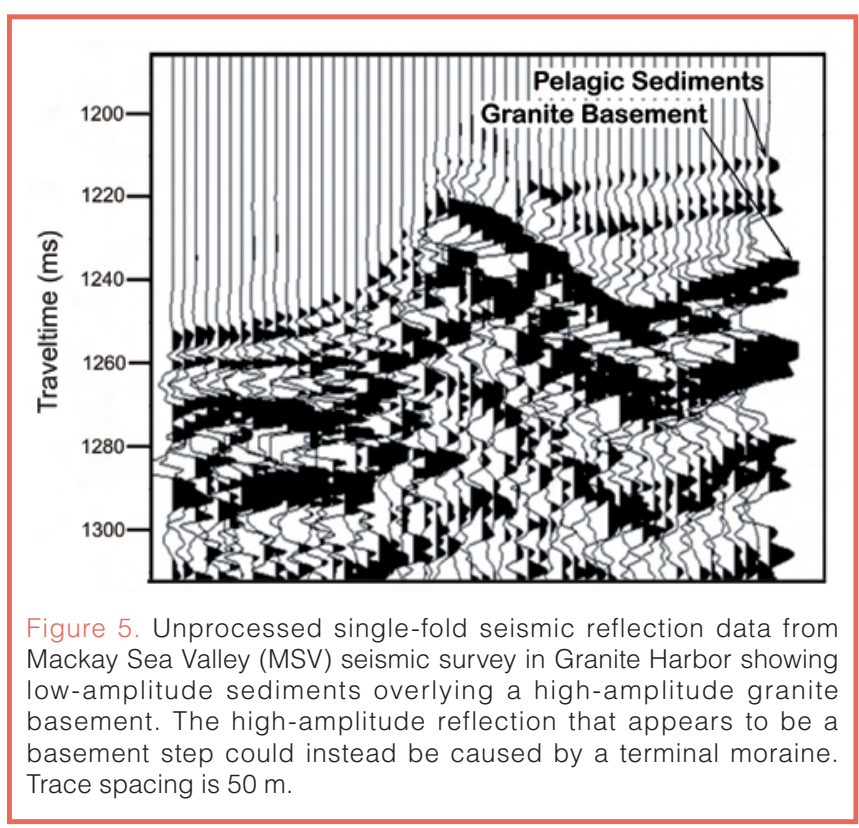


Foundation, the New Zealand Foundation for Research, the Italian Antarctic Research Program, the German Science Foundation, and the Alfred Wegener Institute. The U.S. National Science Foundation supports the over-sea-ice seismic surveys though grants OPP-0342484 and ANT-0732875.

\section{References}

ANDRILL International Science Proposal, 2003. ANDRILL: Investigating Antarctica's Role in Cenozoic Global Environmental Change. ANDRILLContribution 2, University of Nebraska-Lincoln, Lincoln, Neb.

Bannister, S.C., and Naish, T.R., 2002. ANDRILL site investigations, New Harbour and McMurdo Ice Shelf, southern McMurdo Sound, Antarctica. Institute of Geological \& Nuclear Sciences Science Report, 2002/01, 24 pp.

Barrett, P., Sarti, M., and Wise, S.W., Jr., 2000. Studies from the Cape Roberts Project, Ross Sea, Antarctica, Initial Report on CRP-3. Terra Antart., 7(1/2), 209 pp.

Betterly, S.J., Speece, M.A., Levy, R.H., Harwood, D.M., and Henrys, S.A., 2007. A novel over-sea-ice seismic reflection survey in McMurdo Sound, Antarctica. Terra Antart., 14(2):97-106.

Cobb, A.T., 1973. 'Vibroseis' ${ }^{\circledR}$ applications in the Arctic. Proceedings from National Convention, Canadian Society of Exploration Geophysicists, 115-140.

Cook, R.E., 1973. Experimental seismic methods in the Canadian Arctic. Proceedings from National Convention, Canadian Society of Exploration Geophysicists, 47-57.

Davy, B.W., and Alder, G., 1989. Seismic reflection surveys. In Barrett, P.J. (Ed.), Antarctic Cenozoic history from the CIROS-1 drill hole, McMurdo Sound. Bulletin in the Miscellaneous Series of the New Zealand Department of Science and Industrial Research, 245:15-21.

Falconer, T., Pyne, A., Olney, M., Curren, M., Levy, R., and the ANDRILL-MIS Science Team, 2007. Operations overview for the ANDRILL McMurdo Ice Shelf Project, Antartica. In Naish, T., Powell, R., and Levy, R. (Eds.), Studies from the ANDRILL, McMurdo Ice Shelf Project, Antarctica Initial Science Report on AND-1B. Terra Antart., 14(3):131-140.

Florindo, F., Harwood, D., Levy, R., and SMS Project Science Team, 2008. ANDRILL's success during the 4 th International Polar Year. Sci. Drill., 6:29-31, doi: 10.2204/iodp.sd.6.03.2008.

Harwood, D., Levy, R., Cowie, J., Florindo, F., Naish, T., Powell, R., and Pyne, A., 2006. Deep drilling with the ANDRILL Program in Antarctica. Sci. Drill., 3:43-45, doi:10.2204/ iodp.sd.3.09.2006.

Harwood, D.M., Florindo, F., Levy, R.H., Fielding, C.R., Pekar, S.F., and Speece, M.A., 2004. ANDRILL Southern McMurdo Sound Project Scientific Prospectus. ANDRILL Contribution 5, University of Nebraska-Lincoln, Lincoln, Neb., 29 pp.

Horgan, H., and Bannister S., 2004. Explosive Source Seismic Experiments from a Sea-Ice Platform, McMurdo Sound, 2003. Institute of Geological \& Nuclear Sciences Science Report, 2004/15.

McGinnis, L.D., Bowen, R.H., Erickson, J.M., Aldred, B.J., and Kreamer, J.L., 1985. East-West Antarctic boundary in McMurdo Sound. Tectonophysics, 14:341-356, doi:10.1016/ 0040-1951(85)90020-4.
Mertz, R.W., Brooks, L.D., and Lansley, M., 1981. Deepwater vibrator operations - Beaufort Sea, Alaska, 1979 winter season. Geophysics, 46:172-181, doi:10.1190/1.1441187.

Naish, T.R., Powell, R., Levy, R., Florindo, F., Harwood, D., Kuhn, G., Niessen, F., Talarico, F., and Wilson, G., 2007. A record of Antarctic climate and ice sheet history recovered. EOS Trans., Am. Geophys. Union 88:557-558, doi:10.1029/ 2007EO500001.

Rendleman, C.A., and Levin, F.K., 1990. Seismic exploration on a floating ice sheet. Geophysics, 55:402-409, doi:10.1190/ 1.1442849 .

\section{Authors}

Marvin A. Speece, Geophysical Engineering Department, Montana Tech, 1300 West Park Street, Butte, Mont., 59701-8997, U.S.A., e-mail: mspeece@mtech.edu

Richard H. Levy and David M. Harwood, ANDRILL Science Management Office and Department of Geosciences, University of Nebraska-Lincoln, 126 Bessey Hall, Lincoln, Neb. 68588-0341, U.S.A.

Stephen F. Pekar, School of Earth and Environmental Sciences, Queens College, CUNY, 65-30 Kissena Boulevard, Flushing, N.Y., 11367, U.S.A.

Ross D. Powell, Department of Geology and Environmental Geosciences, Northern Illinois University, DeKalb, Ill., 60115, U.S.A. 